\title{
A visual-acoustic duet of painting and music in medieval aesthetics
}

\author{
D.V. Gladkova ${ }^{1}$, D.Yu. Dorofeyev ${ }^{1}$ \\ ${ }^{1}$ Faculty of Oil and Gas, Saint Petersburg Mining University, Saint Petersburg, Russia, \\ ${ }^{2}$ Philosophy Department, aint. Petersburg Mining University, Saint Petersburg, Russia
}

\begin{abstract}
The purpose of this work is to study the visual and acoustic relationship of painting and music in the Middle Ages. When writing the article the authors focused on modern sources and used such important for the socio-humanitarian sciences methods of research as comparative, phenomenological, semiotic, art history, cultural studies and visual anthropology, which determined the interdisciplinary nature of the study, which focuses of the aesthetic specificity of the perception of the phenomenal image. The significance of the study lies in the fact that the results obtained allow to better understand the cultural foundations of the non-verbal way of perception, the peculiarities of medieval culture and aesthetics of Western Europe and its semiotic and symbolic forms, primarily in the perspective of the interaction of painting and music in the sacred and everyday spaces of the existence of medieval man.
\end{abstract}

\section{Introduction}

The deeper you go into the study of the Midieval culture, the more you realize that the understanding of this period as the Dark Ages was limited and simply wrong. In fact, if you open a medieval illuminated manuscript or enter a Gothic cathedral shining with brightly colored stained-glass windows and striking exterior decor, where there is an organ choir that exalts the soul, you are confronted with a special culture of light. However, such an assessment of the Middle Ages is no longer supported, so medieval studies discover more and more of the semantic boundaries of this culture, helping us to understand the origins of European culture. But what is the relevance of turning to the aesthetics of this era for us, beyond historical, cultural, and educational interest, at the beginning of the 21 st century?

Let us remember that the development of European culture, starting from the 17 th century, took place under the obvious priority of writing - thus, epistolary communication gained great importance in the culture and discourse of the noble elite [1]. But, of course, the central influence at this time was in the theoretical, scientific, and conceptual form of thinking and expression ${ }^{1}$. Understandably, because the scientific revolution, which began with the works of Copernicus, Galileo, and Kepler,led F. Bacon, Newton, and Descartes in

\footnotetext{
${ }^{1}$ This process also influenced Russia, where since the 17 th century and especially since the 18 th century, the presence and recognition of the importance of scientific, theoretical, and philosophical works in culture has significantly increased, which is especially noticeable in the attitude towards Plato and the reception of his dialogues during this period:[2].
} 
their works to form a new, mechanistic picture of the world, based on the principles of mathesisuniversalis, which marked unexpected upsurge in the development of the natural science. For two or three centuries, there has been a huge enthusiasm, connected with rational, verbal-conceptual cognition of the world, which has become determination of the worldview values of several generations and has strictly subjugated all other approaches. But, as historical experience shows, the apotheosis and absolutization of one attitude sooner or later leads to its stagnation and dogmatization. A sense of the crisis of the new European rationality at the beginning of the 20th century was obvious, and the culture offered revolutionary breakthroughs in all the fields: Einstein's science offered something new, fundamentally different from Newton's understanding of time, space and the world itself ${ }^{2}$; philosophy, including such movements as existentialism, philosophy of life, and phenomenology, transcended the classical framework of rationalism, empiricism, and Kant's critique of human understanding; the literary works of Proust, Hofmannsthal, and Kafka developed a new understanding of the language; the paintings of Impressionism, Abstractionism, Cubism, and the avant-garde offered a radically new form of figurative understanding and representation of the world, etc.

In this context, the priority of verbal, conceptual, and rational mechanisms of human perception and explanation of the world has been seriously shaken, and more and more attention has been given to non-verbal methods: visual and acoustic that have come to be seen as original, mostly independent of the defining power of words. In fact, there was a new discovery of sensitive forms of art, a new understanding of the image and a new vision of the aesthetics [from Gr. "atesis" - sensory sensation, perception] happened that prepared a true visual and iconic turn in culture, history, and science [3, 4].Characteristically, one of the most authoritative historians and theorists of art in the twentieth century, E. Gombrich, actively refers to the original research in the field of new approaches in the psychology of perception and representation of the aesthetic image [5].This led to adventurous experiments in painting and music, as these art forms were associated with visual and acoustic perception. That trend developed throughout the 20th century, and was especially accelerated at the end end, thanks to the introduction of new Internet technologies into everyday life, which radically changed our existence and led, in fact, to the virtual visualization of the whole culture ${ }^{3}$. Those conditions, for critical understanding of our difficult time, turned to a careful study of the culture and aesthetics of the Middle Ages, where the visual-acoustic component was most significant to the everyday picture of the world and the identity of each person, whether peasant, feudal lord, monk,or prince. Incidentally, the previous century was the heyday of medieval studies with such names as D. Heising, M. Bloch, L. Fevre, F. Aries, E. Gilson, J. de Goff, W. Eco, and others. The last name in this list has a special meaning for us because this Italian scholar was not only the greatest researcher of the medieval culture but also one of the eminent representatives of semiotics [6]. This alliance allowed Umberto Eco to develop based on a medieval understanding of the aesthetics, semiotics of sound, light, and color in music, painting, and the theories underlying them [7], which permeated all Western European painting until the 15 th and 16th centuries. The relevance of this approach manifested, particularly, in showing that the semiotic system of the visual image is fundamentally different from the order of construction of the semiotic system of the word, explained by F. Saussure (one of the

${ }^{2}$ It should be noted that the most complete and profound overcoming of the Newtonian and, in general, the new European scientific picture of the world was realized and comprehended in the 20th century synergetics, both in relation to nature and man and society as a whole [8].

${ }^{3}$ And more clearly in everyday life, the close relationship between the visual, the acoustic and the narrative is revealed in consumer advertising, which we perceive daily in the media as well as in any public space, and this relationship requires serious reflection [9]. 
founders of semiotics), is also confirmed by the fact that modern semiotic research is actively studying the field of color semiotics, semiotization of visual codes, semiotics of visual and acoustic means, etc. [10]. These are very important horizons because they are not limited to the all-pervading semiotics of the word as structuralists and post-structuralists did, e.g., R. Bart [11]; they addressed the problem of the nonverbal semiotic systems, primarily visual image and acoustic sound. So, in this context, we should pay attention to how organically the visual image of a painting and the acoustic sound of music were organically interconnected in the everyday life of a medieval person, which was permeated by them in their worldview, formed from this organic duo, at a pre-reflective value and aesthetic level, this undifferentiated synthesis of the two most important forms of sensory human perception.

The relevance of the interaction of music and painting is well-known and stems from the crucial role of art in the education, life, history, and culture of allmankind. Music and painting embodied in a visual-acoustic form, have a certain understanding of the world, which, even at a pre-reflexive level, has a very strong, including the religious, aesthetic, axiological, and emotional effect on people. Studying the mechanisms of this influence, its genesis, and the process of its implementation is an exciting and urgent task for our time; moreover, the problem of non-verbal bases of human perception of the world around us comes to the fore nowadays ${ }^{4}$. Let's not forget that most of the information, about $80-85$ percent, a person receives with the help of visual and acoustic perception. Their interaction in this work is examined through music and painting. Indeed, these forms of art very often relate to each other, even though they are based on different sensory perceptions, which, however, can give the beginning to a sensory impression of the other area. It is not accidental that the great Italian artist Leonardo da Vinci called music the sister of painting because music and painting have a lot in common.

First of all, music and painting are based on the most important human senses, visual and acoustic perceptions, and their importance in culture can hardly be overestimated. They are united by the strongest influence they have on man and very often one of them actualizes the other in the imagination. The great Goethe said that "color can be even felt" [12], so he emphasized the importance of studying the present, reaching mutual penetration of the dialogue of sensory forms of human perception, and the dialogue between the visual and the acoustic is the most important.

Secondly, any work, both in the fine arts and in music, tells us of the emotional experiences and feelings of their creators and also involuntarily expresses the spirit of the time itself, the picture of the world existing in it, the value and aesthetic order, the principles of human (self-) understanding, nature, beauty, truth, etc.

Thirdly, music and painting have general canons: color, rhythm, and composition. The skillful combination of these elements makes it possible to evoke vivid visual images, certain kinds of "musical pictures" with the help of music, and a sense of sound and even melody through painting. The phenomenon of synesthesia has long been known in art history, when one sensory perception evokes the sensation of another sensory perception area, for example, awakens in the viewer a sensation of "warm color" - this fact was especially known to the great artists of the Florentine school [13]. Music has an unrivaled ability to create the brightest visual images, maximally activating the creative ability of the imagination.

As we can see, Leonardo da Vinci was right, that music and painting are soul mates! There is a huge number of examples of their relationship. For example, such famous

\footnotetext{
${ }^{4}$ In this sense, it is worth noting that the unity of visual and acoustic communication was the basis already in Ancient Greece, fundamentally conceptualized by Plato, and this same attitude was actualized in the 20th century, for example, in the work of the early T. Mann [14].
} 
Russian composers as N. Rimsky-Korsakov and A. Scriabin had the so-called "color ear" or synopsis. Each musical tone was presented to them in the form of a certain color and in connection with it had one or another unique, emotional coloring. Synopsis is not the only form of the relationship between color and sound. For some composers, visual and color representations are so strong that they simply cannot help but create musical compositions based on them. A similar situation exists among the artists who are inspired by the splendor of musical compositions, hear the sound and create a visual image (And this applies not only to art: for example, it is known that Heinrich Heine who went blind in his old age, asked to take him to a balcony overlooking the Champs Elysees, since the noise of the city awoke in him his visual imagery) [15].These are important problems of the psychology of artistic creation and characteristics of the organization of human consciousness; for example, one of the main philosophers of the last century, the Frenchman Maurice MerlotPonti, who dealt with the problems of the phenomenology of perception, turned to the study of design with the use of visual forms of the picture of the world in painting [16]. Certainly, the synthesis of music and the visual arts has been actively developed in theater, where the combination of music, costumes, and scenery is so important. And it is important to remember that back in Ancient Greece, where the tragic theater was born, the visual, acoustic, and somatic components were inseparable in the process of perceiving the image. If we talk about the present, the synthesis of music and painting is actively represented in the art of cinema (for example, Andrei Tarkovsky constantly used in his films the accentuated synthesis of the visual image of the painting and the acoustic image of music as the strongest expressive technique, depicting the former by the rules of the latter and vice versa), various forms of animation, light music, performance, and various kinds of network art; it is now difficult to imagine human life without them. [17].

But here we are primarily interested in the experience of medieval culture, and we are moving to it.

The Middle Ages is a unique historical period spanning more than a millennium, roughly from the fifth to the sixteenth centuries (however, the time frame is quite conditional, since while in Italy the quattrocento already refers to the early Renaissance, then in Northern Europe and Russia the sixteenth century is still the middle ages); we focus on the heyday of the Western European Middle Ages, which took place in the 12th-13th centuries [18]. The life of a medieval man was not only interesting but brutally dramatic. Suffice to recall the numerous wars, crusades, witch hunts, diseases of all kinds and epidemics. Faith in God and life after death helped people to cope with the oppression of harsh reality. Thus the church, as a mediator between the heavenly and earthly worlds, had a dominant influence on the whole human life and all the forms of art. Medieval thinkers (Augustine, Boethius, R. Bacon, etc.) actively addressed the study of the problem of the sign, mainly in the context of scholastic logic, but also in the visual image; therefore, modern scholars rightfully speak of medieval semiotics [19]. According to the Christianworldview, which is based on the principle that the Creator puts into creating, not only the surface, obvious, but also the latent, deciphering meaning; the art of the Middle Ages is symbolic and allegorical (for example, every work of pictorial image was literally at this time was filled with symbols of color, plants, clothes, posture, plot, etc., which for most modern viewers remains a hidden and "unreadable" things). Conventionally, it can be divided into two independent parts: ecclesiastical and secular cultures.

\section{Church culture in the middle ages}

The main themes of the artistic works were determined primarily by religious content, plots from the Old and New Testaments, and the lives of the saints. The Church, as the 
center of the medieval world in general and art in particular, actively integrated such forms of painting as frescoes, mosaics, stained glass, and, to a lesser extent, illuminated manuscripts or books with miniatures and liturgical texts. Thumbnails of sacred manuscripts can be defined as a special genre of art, a decorated text with pictoralinserts and ornamental details, which ancient culture did not know in this form and which were widely used in the Middle Ages; along with the church miniatures, there were secular ones, such as the famous "Luxurious Hour Book of the Duke of Berry". A fresco is a wall painting on raw stucco. Antique frescoes, primarily in the ancient Roman tradition, were developed in both Eastern and Western Christianity; it is enough to walk through the ancient churches of Rome, Athens, or Moscow; but even among these masterpieces, the greatness of Giotto, who created enormous cycles of fresco compositions in Assisi and Padua, cannot but amaze. The same genesis characterizes the more expensive to produce mosaic, which forms unique luminous wall and dome images from small smartparts, for example, in the Sicilian cathedrals of Palermo, Cefalu, and Montreal (incidentally, in antiquity, the mosaic was mainly on the floor).Stained Glass can be defined as a decorative composition of pieces of colored glass, especially in Catholic medieval art, which is very closely associated with the theology of light and the organization of the space of in the classical Gothic cathedral.The main purpose of church art is to convey to people what that they cannot understand through the text of Scripture.Church Father Basil the Great and Pope Gregory the Great called painting "a book for the illiterate," adorning the house of God and reminding of the righteous life of the saints, i.e. fulfilling mainly didactic and decorative functions. This is quite understandable: most parishioners could not read and were acquainted with the provisions of Christianity only in visual form, through images on the walls of cathedrals and churches, and in acoustic, through sermons of priests. A special role was assigned to church music, which, in conjunction with the visual component of the temple, organized the consciousness of people in a direct correlation with God and religious orientation. For example, the music of J.S. Bach was written specifically for its performance in the temple, where it acquires a completely different, much more sacred sound than in the concert hall, and, accordingly, its effect on the person becomes special.

J. Heyzing emphasized that the main feature of medieval culture, especially the later one, is it's emphasized visual nature; it is mainly a visual era because people thought, felt, lived in visual images, that is why the symbolism of flowers was so important because it created what the scientist named in relation to the Ghent altar created by Jan and Hubert van Eyck in St. Bavo'sCathedral of Ghent "the mystery of everyday life;" that mystery was expressed in a visual form, in which everyone who perceives it "lives a treasure of the ineffable." [20].

Looking through the phenomenon of medieval Gothic stained glass windows, one can see the visual miracle that reveals the mysteries of the medieval worldview, and with aspiration turn to the stained glass windows of the amazing Chartres Cathedral, known as the "Glass Bible" (one cannot but mention the stained glass windows of Notre Dame de Paris, cathedrals in Reims, Bourges, Soissons, Canterbury, and other European cities).

The history of Chartres dates back to the middle of the $1^{\text {st }}$ millennium. The city's cathedral was laid out on the site of an ancient sanctuary of the Druids. It was believed that sacred energy emanated from this place. Such a place was chosen on purpose: it marked the victory over the errors of the pagans and the praise of faith in the true God. On the site of the present cathedral in the 9th century, there were temples in which the most revered Christian relic, the shroud of the Virgin Mary,was kept. The process of building the modern cathedral began at the end of the 12th century. In 1260, the temple was officially inaugurated with the help of King Louis IX. The appearance of the Chartres Cathedral has not changed since then. The pride of the Chartres Cathedral is the astronomical clock, the labyrinth, symbolizing the path of the believer to God, the "Chartres Blue" - a shade of blue 
on the stained glass windows. The stained glass windows are considered the most unique attribute of Chartres Cathedral - their total area is more than 2,000 square meters, and the number is more than 170 !

The word " stained glass" comes from fr.vitrage - glazing and lat. vitrum - glass. The exact period when stained glass appeared is unknown. Stained glass windows have been found in many ancient cultures such as Rome, Byzantium, Ancient China, and Egypt, but, of course, the medieval Gothic stained glass windows are unsurpassed.

Every medieval cathedral has its meaning and idea. Chartres Cathedral symbolizes a picture of the world of heaven and earth, embracing the diversity of medieval thought, which is why its stained glass windows are considered "the light of Christian teaching." The ensemble of stained glass windows, which have been created in Chartres Cathedral for centuries, is unique. (At present, Notre Dame in Chartres has the stained glass windows of the second half of the 12th to the first half of the 13th century). The ideas of the stained glass windows express the most diverse biblical subjects and even scenes from the life of Christ, Our Lady, saints, kings, and knights.

In a church, a stained glass window is a "window to heaven", which with the help of true light illuminates the hearts of parishioners. This has to do with a certain color symbolism. Gold is a symbol of the radiance of the divine glory in which the saints abide. White is a symbol of purity and integrity, of belonging to the divine world. Black, on the one hand, is a symbol of hell, the maximum distance from God, and, on the other hand, a sign of sadness and humility. (Sky) blue is the symbol of the Virgin, meaning purity and righteousness. Blue symbolized something divine, heavenly, the incomprehensibility of mystery and depth of revelation. Red is a symbol of redeeming blood, martyrdom. Green symbolizes eternal life, the color of the Holy Spirit [21].

Contemplation of true color and being in the special atmosphere created by stained glass windows help people get closer to God and know the mystery of existence. Stanford University Professor B.V. Pencheva in her recently published fundamental research emphasizes and reveals the deep connection between the visual arts, architecture, and music, which are organically united in the medieval temple [22].

Church music is an integral part of the Christian Cathedral now, but it had a special significance in the Middle Ages. After all, the high spirituality and ascetic nature of the Christian religion was "voiced" by music. The main aesthetic theory of music in the Middle Ages was created by Boethius, based on the mathematical principles of proportionality and symmetry, designed to elevate and perfect the soul; incidentally, the cosmology of Chartres Cathedral, including the role of stained glass windows, will also be built on the same principles (Eco U). The musical symbol of the Middle Ages was the Gregorian choral, which contained the whole unity of being. Church music is characterized by numerical symbols. The number "three" has a special meaning. Thus, the beginning, middle, and end of a piece of music correspond to the divine trinity, and the three types of musical instruments signify the three Christian virtues: faith, hope, and love. In both music and painting, the concepts of "top" and "bottom" were very important.The top was associated with the soul and heaven, and the bottom with the body and earth. Thus, church singing exalted man above the temporality of the world and switched him to a sacred hypostasis [23]. The influence of church music was enhanced by the acoustical capabilities of the churches. High arches reflecting sound created the effect of the divine presence. Thus cathedral architecture, stained glass windows, and music live together their mysterious life. Their duet reveals the souls of people, thereby initiating them into the liturgical secret [24].The influence of church music was enhanced by the acoustical capabilities of the churches. High arches reflecting sound created the effect of the divine presence. Thus cathedral architecture, stained-glass windows, and music live together their mysterious life. Their duet reveals people's souls, thereby initiating them into the liturgical mystery. 
Now let's consider the visual-acoustic duet of painting and music in the secular culture of the Middle Ages.

\section{Secular culture in the middle ages}

The world around medieval's life was a symbol of some higher reality, a manifestation of the Creator's will and wisdom. In all spheres of culture, the language of symbols and allegories was used. As we have already noted, color symbolism, which was used not only in art but also in everyday life, had particular meaning. The purple color represents dignity, power, piety, and generosity, it's a symbol of kings. Gold symbolizes wealth, nobility, and power. Red is a symbol of courage, strength, nobility, power, and noble origins. Blue is a symbol of greatness and beauty, generosity and fidelity. Green is a symbol of life, freedom, youth, and nature.

Various literary works - chronicles and book miniatures (Vienna Genesis; Codex from Rossano; CarminaBurana) tell us about the meaning of color symbolism. Thumbnails are small illustrations in a manuscript book. In addition to religious subjects, images of secular content were common in miniature. Therefore, illustrated manuscripts, in addition to their artistic value, represent an invaluable source of historical information. Examples include the Codex Manessethe fine chronicle that tells about the life of a knight: tournaments, feasts, and exploits in the name of the "beautiful lady", or the already mentioned "Luxurious Hour Book of the Duke of Berry". The illustrations pay special attention to detail: patterns, ornaments, and the correct rendering of emotional atmosphere and everyday scenes. It is noteworthy that even the musical notes were decorated with pictorial miniatures. An important feature of book miniature is the reflection of the relationship between the real and the mystical world, the subtle interweaving of secular and religious life [25].

As mentioned earlier, music was an integral part of medieval life. However, it was very different among the people and in the temple. Whereas in the cathedral church singing created an atmosphere of pure spirituality, among the people music set the stage for carnivals and feasts, games, and labors. Carnival festivals and related rituals, in particular, musical ones, occupied an important place in the life of medieval man, which in some places determines the place, which was shown by M.M. Bakhtin (who introduced the concept of "carnival attitude" into wide scientific use) in his classical study [26]. Carnival became a second life for the people, festive and carefree, removing all hierarchical and normative, including ecclesiastical, restrictions that applied at other times. And carnival music carried the spirit of freedom, the irony on social order and church control. Not a single important event in the life of medieval man occurred without musical accompaniment. The music here is always visually plastical, as represented by the dances of those present: visually and acoustically, sound and color here were inseparable from each other and were embodied in a specially organized carnival body. One is immediately reminded of Dionysius, the free ancient Greek festivals with singing, dancing, playing scenes from the life of Dionysus, which served as the source of "the birth of tragedy from the spirit of music," if we refer to the famous work on this subject by Friedrich Nietzsche. The spirit of this festival is perfectly expressed in such paintings by Peter Brueghel the Elder as "The Battle of Shrovetide and Lent," "The Wedding Dance," "The Peasant Dance," and others.

Secular music conditionally is divided into folklore and knightly. The bearers of folk music were jugglers and minstrels. These wandering actors were versatile masters. They easily combined singing, dancing, and playing various instruments with circus art and puppet theater. The other side of secular music was the culture of chivalry, and all the charms, reflected in the music and poetry of the troubadours. Their art was mainly 
concerned with love lyrics. The words and melody of the troubadours' songs are distinguished by sophistication and fine artistic taste. The poetry of the troubadours was one of the first attempts to bring a love-lyric mood to the rather rigid and sometimes severely organized medieval world, thereby bringing it to new values of the personal heart experience [27].

When studying medieval literature, it is hard to find works without mentioning the music. The most famous musical legends of King Arthur and the Knights of the Round Table convey a whole panorama of musical episodes illustrated with colorful miniatures. In them, the music reveals and complements the ideological and emotional content. The medieval painting itself very often used the images of singers and musical instruments in the system of pictorial images (Merlozzo da Forli’s "Angel"; Pierro de Francesca's "Christmas"; Jan van Eyck's "Musical Angels" Ghent Altarpiece and others). Thus, the duet of music and painting, this union of non-verbal forms of expression, helps us to understand the peculiarities of attitude, worldview, the storehouse of values, everyday life, to understand the images of God, man, and the world in a way that we probably would never understand on the basis of literary works [28].

\section{Conclusion}

Medieval art played an important role in world culture. The Middle Ages are the creators of new and contrasting forms of the relationship between music and painting, in which people tried to convey a complete picture of the world and comprehend all the laws of the universe through certain symbolism,. In this study we have tried to analyze the cultural foundations of non-verbal ways of perception, embodied primarily in the visual image and acoustic sound (i.e. painting and music), in the Middle Ages, referring for this purpose to interdisciplinary research methods (semiotic, phenomenological, cultural, art history, etc.).It was important to show the originality of non-verbal medieval semiotics presented both in sacred and everyday space (i.e. in the temple and in the street), which was the most important part of the medieval picture of the world, and to emphasize its differences from verbal semiotics defined by the written word, reason and scholastic concepts. This was done on the basis of the close relationship between the visual (figurative) and acoustic (aural) components of medieval consciousness, which represented an organic unity at the prereflective level. Features of medieval church art (fresco and mosaic painting, stained glass, music) make it possible to actualize visual-acoustic way of perception and understanding of the world and man, to analyze mechanisms of its formation, and analysis of everyday life of medieval man reveals great influence on his existence and worldview of visually perceived image and acoustically perceived sound. Such knowledge is especially relevant for the modern culture of the 21 st century, for which visual image and acoustic sound are extremely important.

The reported study was funded by RFBR, project number 20-011-00385a "The iconography of ancient and medieval philosophers in Orthodox churches: the specificity of the visual representation of man in Russian culture".

\section{References}

1. M.I. Mikeshin The role of the epistolary genre in the philosophical discourse of the noble elite. Bulletin of the Pushkin Leningrad State University,3, 8-25 (2020) 
2. O.V.Bezzubova, O.Yu.Goncharko, M.I. Mikeshin Byzantine history of Plato's dialogue and its reception in Russia in the 18th-19th centuries. Bulletin of Tomsk State University. 456, 85-92(2020)

3. O.V. Bezzubova Iconic turn and the science of images. Visual communication in sociocultural dynamics. Collection of articles of the II International scientific conference, 418-424 (Moscow,2016)

4. O.V.Bezzubova "Visual turn" in humanities research and historical scienc.The role of visual sources in the information support of historical science: a collection of article: 62-72. Ed. by A.G. Golikov, (Moscow, 2019)

5. E. GombrichArt and Illusion: A Study in the Psychology of Pictorial Representation. $5^{\text {th }}$ Ed.,(London, 1977)

6. U. Eco Theory of Semiotics,(Bloomington, London,1976)

7. U. EcoEvolution of medieval aesthetics,(Saint-Petersburg, 2004)

8. N.A. Vakhnin Man, nature, society: synergetic dimension.Jornalof Mining Institute. Saint Petersburg.221, 761-766(2016)

9. A.V. Veretennikova, D.A. Shchukina Image, text, logo [element correlation in consumer advertising]. Modern educational technologies in training specialists for the mineral resource complex. III All-Russian conference 05-06 March 2020. Collection of scientific papers. Saint Petersburg: SPG,1357-1364(2020)

10. L.F. ChertovSign prism: articles on general and spatial semiotics, (Moscow,2004)

11. R. Bart Selected Works. Semiotics. Poetics,(Moscow,1994)

12. Goethe. The doctrine ofcolours, (Saint Petersburg, 2019)

13. B. BurnsonPainting of the Italian Renaissance,(Moscow, 1965)

14. D.Yu.Dorofeev Visual communication of love in Athens and Venice: Plato and Thomas Mann.School. Ancient Philosophy and Classical Tradition, 14[2], 637664(2020)

15. E.V. Lysova "Picturesque music" and "musical painting": ideas of coexistence.Bulletin of the Mordovian University, 46-49 (Saransk, 2008)

16. M. Merlot-PontiEye and Spirit,(1992)

17. V.G. Vlasov Moment and duration: artistic time and space in architectonic-visual arts. To the problem of "synthesis of arts".Electronic scientific journal "Architecton: University News",2, 66 (2019)

18. K. Brooke Renaissance of the XII century.Theology in the culture of the Middle Ages, 119-227 (Kyiv, 1992)

19. S. Meier-Oeser [ed.] Medieval Semiotics.Stanford Encyclopedia of Philosophy,(Stanford, 2008)

20. J. HeizingAutumn of the Middle Ages. Studies of life forms and ways of thinking in the 14th and 15th centuries in France and the Netherlands,(Moscow, 2004) 
21. A. JordanAlyce Les vitraux narratives de la cathedrale de Chartres: Etude iconographique. Colette Manhes - Deremble, Jean - Paul Deremble.Speculum,72[2], 524-526 (USA, 1997)

22. V.PentchevaBisserIcons of Sound: Voice, Architecture, and Imagination in Medieval Art [Music and Visual Culture],(Routledge,2020)

23. M. Rice Interaction of painting and music in European art.Israel XXI century: music magazine, 5, 47 (2014)

24. E.I. Rotenberg The art of the Gothic era, (Moscow: Art, 2001)

25. J.C. Webster The Labors of the Months in Antique and Mediaeval Art to the End of the Twelfth Century,(New York: AMS Press,1970)

26. M.M. Bakhtin The work of Francois Rabelais and the folk culture of the Middle Ages and the Renaissance,(Moscow, 1990)

27. B. Benjamin, J. DavidMusic and Culture in the Middle Ages and Beyond: Liturgy, Sources, Symbolism. Renaissance Quarterly. Rothenberg, eds.,71[1], 372-374 (Cambridge: Cambridge University Press, 2016)

28. M.A. SaponovMinstrels. A book about the music of medieval Europe,(Moscow: Classic,2004) 